\title{
PRIORITAS KAJIAN HUKUM DALAM MENDUKUNG PEMBANGUNAN KELAUTAN DAN PERIKANAN
}

\section{Priorities Study on Laws To Support The Development of Marine and Fisheries Sector}

\author{
Bayu Vita Indah Yanti dan Zahri Nasution \\ Balai Besar Penelitian Sosial Ekonomi Kelautan dan Perikanan \\ JI. KS. Tubun Petamburan VI Jakarta 10260 \\ Telp. (021) 53650162, Fax. (021)53650159 \\ Email: bviy1979@gmail.com
}

Diterima 23 Agustus 2013 - Disetujui 29 Nopember 2013

\begin{abstract}
ABSTRAK
Sektor kelautan dan perikanan merupakan bidang yang memiliki sumber daya potensial untuk menghasilkan devisa negara. Belum adanya perumusan kebijakan yang integral dan implementasi dalam bentuk peraturan perundangan yang baik, telah menyebabkan bidang kelautan dan perikanan (KP) tidak dapat dimanfaatkan secara optimal. Pendekatan dan upaya terpadu perlu dilakukan, guna menilai kondisi peraturan perundangan atau hukum yang mengawal pembangunan $\mathrm{KP}$, semantara itu sosialisasinya pada pemangku kepentingan belum/tidak optimal. Dari perspektif konstruksi hukum terhadap pembangunan KP harus selaras/harmoni dengan peraturan perundangan sector terkait dan ketentuan-ketentuan hokum dan sinkron dengan ketentuan-ketentuan hokum internasional. Tulisan ini bertujuan menentukan prioritas kajian aspek hukum atau perundangan dalam mendukung pembangunan KP. Studi dilakukan dengan menggunakan pendekatan peraturan dan perundangundangan (legal approach study). Hasil studi mengisyaratkan perlunya empat prioritas kajian hukun yang perlu dilakukan, yaitu terkait dengan (1) perencanaan pembangunan nasional, (2) pengelolaan sumber daya kelautan dan perikanan, (3) pemerintahan daerah dan otonomi daerah, (4) penataan ruang dan bisnis kelautan dan perikanan.
\end{abstract}

Kata Kunci: kajian hukum, perencanaan pembangunan, pengelolaan sumber daya, pemerintahan daerah, penataan ruang dan bisnis

\begin{abstract}
Marine and fisheries sector is an area that has the potential to generate foreign exchange. The absence of an integrated policy formulation and implemented properly, has led the field of marine and fisheries have not been used optimally. Efforts in an integrated approach is needed to assess the condition of the law on which the development policies of marine and fisheries sector. Legal materials of marine and fisheries sector requires the formulation of a comprehensive policy, in order to function as a main political for countries that strengthen instistution economic development of marine and fisheries. Construction of marine and fisheries sector, by law, also need to pay attention to issues that have strong relationships with international law. This paper aims to determine the priority review of the legal aspects and legislation in support of the development of marine and fisheries sector. The study was conducted by using a legal approach study. The results shows there are at least five priority review of the law that need to be done, in relation to national development planning, management of marine resources and fisheries, local government and regional autonomy, spatial planning and marine and fisheries bussiness.
\end{abstract}

Keywords: legal study, development planning, management of resources, local government, spatial and bussiness planning 


\section{PENDAHULUAN}

Keberhasilan implementasi peraturan perundang-undangan di sektor kelautan dan perikanan sangat membutuhkan adanya pengawalan peraturan perundangan yang menjadi perangkat hukum dalam menjaga kesinambungan usaha perikanan, keadilan dalam pemanfaatan sumber daya, keamanan berinvestasi, dan kesetaraan dalam memanfaatkan potensi ekonomi. Indonesia telah memiliki berbagai peraturan yang dibentuk dalam rangka membangun bidang Kelautan dan Perikanan (KP), namun sampai saat ini pelaksanaannya belum dapat memenuhi kebutuhan masyarakat yang berkepentingan, serta rasa keadilan dan kepatutan. Menurut Siombo (2010), berbagai peraturan nasional, mulai dari Undang-Undang (UU) sampai peraturan menteri yang ditetapkan dan berbagai konvensi internasional yang telah disahkan oleh pemerintah Indonesia, sampai saat ini belum dapat mengatasi permasalahan di bidang perikanan.

Soekanto dalam Abdurrahman (2009), menyebutkan bahwa derajat tinggi rendahnya kepatuhan hukum terhadap hukum positif tertulis, salah satunya didasarkan pengetahuan dan pemahaman hukum. Pengenalan suatu kebijakan baru seringkali mengalami kendala, karena masyarakat kurang memahami dengan baik tujuannya. Tidak adanya aparat pendamping yang membantu menjelaskan kepada masyarakat, membuat suatu kebijakan baru tidak mudah terinformasikan dengan baik. Pembenahan komponen substansi sistem hukum di bidang KP wajib dilandasi adanya kepentingan memberdayakan masyarakatnya. Pembenahan komponen substansi sistem hukum selama ini, dirasakan masih ada campur tangan pihak tertentu (pemodal/investor) yang mempunyai kepentingan dengan penyempurnaan atau dibuatnya suatu aturan.

Campur tangan tersebut tidak jarang menimbulkan kesulitan bagi pihakyang merumuskan kebijakan dan bahkan ada yang merugikan masyarakat KP itu sendiri. Pemberdayaan seluruh strata komponen masyarakat KP perlu dilakukan, mengingat adanya potensi yang besar apabila mengikutsertakan mereka. Pemerintah dituntut dapat merumuskan substansi sistem hukum nasional yang tidak berpihak kepada salah satu pihak saja. Tuntutan ini memerlukan kecermatan dan ketelitian perumus kebijakan, guna menyempurnakan sistem hukum ataupun menciptakan produk hukum. Penyempurnaan hukum di sektor KP memerlukan Sumber Daya Manusia (SDM) yang handal. Keahlian mutlak dibutuhkan untuk dapat merumuskan substansi sistem hukum yang mudah dipahami, serta tidak ada celah untuk disalahgunakan.

Pembangunan KP secara hukum, juga perlu memperhatikan masalah yang mempunyai hubungan erat dengan ketentuan hukum internasional. Merujuk pada hal tersebut, pembangunan hukum KP tidak dapat mengabaikan ketentuan yang terdapat dalam konvensi internasional yang telah diratifikasi. Menurut Umar (2003), bahwa tindakan Indonesia selama ini lamban dalam hal meratifikasi suatu konvensi internasional, dan apabila telah meratifikasi kurang sigap untuk menindaklanjuti dalam peraturan nasional. Kunci utama keberhasilan pembangunan KP sangat tergantung pada keputusan politik, baik dari lembaga eksekutif maupun legislatif dalam merumuskan dan menetapkan kebijakan KP nasional, termasuk penyediaan dana anggaran yang dibutuhkan. Umar (2003), mengungkapkan bahwa hukum di Indonesia merupakan masalah yang sangat kompleks dan memerlukan penataan kembali secara total terutama terkait keserasian dengan peraturan perundangan sektor lain, misalnya lingkungan hidup, kehutanan dan pekerjaan umum.

Supriatna (2008), mengungkapkan bahwa sejak otonomi bergulir, terjadi tumpang tindih kewenangan serta peraturan antara pemerintah pusat dan daerah, antara sektor yang satu dan sektor lainnya, antara kebutuhan umum dan masyarakat tertentu di suatu lokasi. Konteks pemanfaatan kekayaan sumber daya di Indonesia, masih sering menimbulkan ketidakseiringan kepentingan antara sektor pemerintahan, masyarakat, dan swasta. Kasus yang sering terjadi dan tidak dapat dihindari, apabila di dalam kawasan tersebut ditemukan bahan tambang (seperti minyak, batubara, dan lain-lain) yang sangat menguntungkan. Konflik antara pemerintah pusat dengan pemerintah daerah bisa muncul karena adanya kepentingan yang berbeda. Tujuan dilakukannya studi ini, yaitu menentukan prioritas kajian aspek hukum dan perundang-undangan dalam mendukung pembangunan KP. 


\section{METODOLOGI}

\section{Pendekatan Kajian dan Ruang Lingkup}

Pendekatan kajian hukum KP mempelajari berbagai hukum dan peraturan perundangundangan yang terkait dengan sektor KP mulai dari bagian hulu hingga bagian hilir. Pendekatan kajian yang dilakukan adalah pendekatan hukum normatif sebagai sebuah norma dan sebagai kenyataan. Penelitian dilakukan dengan menelaah permasalahan terkait dengan bidang kelautan dan perikanan dalam perspektif hierarkhisnya. Dengan cara demikian diketahui sejauhmana pembangunan kelautan dan perikanan sudah diwadahi dan atau didasarkan atas peraturan perundang-undangan yang menurut hierarkhinya sudah sesuai dengan kebutuhan pembangunan tersebut. Berdasarkan pendekatan normatif yang dikemukakan dalam Renstra KKP ini dapat diketahui sejauhmana tujuan pembangunan kelautan dan perikanan sudah didukung dengan peraturan perundang-undangan berdasarkan tujuan yang ingin dicapai oleh KKP.

\section{Lokasi dan Waktu}

Penelitian ini dilakukan di Bogor dan Jakarta termasuk lokasi yang digunakan sebagai tempat verifikasi data peraturan perundangan yang berlaku terkait dengan pembangunan kelautan dan perikanan, terutama kaitannya dengan program minapolitan. Waktu penelitian dilakukan selama 90 hari kerja dalam rentang waktu bulan April hingga Agustus 2011.

\section{Data dan Sumber Data}

Data utama yang digunakan adalah data sekunder untuk kemudian dilakukan klarifikasi data di lapangan. Data sekunder utama berasal dari bahan hukum primer yaitu bahan-bahan hukum yang mengikat, bahan hukum sekunder yang merupakan bahan hukum penjelas dari bahan hukum primer, dan bahan hukum tertier. Sumber data utama adalah Biro Hukum dan Hubungan Antar Lembaga Kementerian Kelautan dan Perikanan.

\section{Metode Pengumpulan dan Analisis Data}

Metode pengumpulan data yang utama dipergunakan pada penelitian ini adalah studi kepustakaan terutama pada bahan hukum primer. Penelitian dilakukan sampai pada taraf sinkronisasi vertikal. Hal ini untuk melihat sampai sejauhmana hukum positif tertulis yang ada serasi atau ada pula yang bertentangan jika dilihat dari sudut hierarki peraturan perundang-undangan (Soekanto, 2010).

Analisis data yang digunakan adalah analisis deskripsi dengan menggunakan metode perbandingan hukum. Dalam hal ini, dilihat perbandingan materi muatan yang terkandung dalam peraturan perundang-undangan terkait dengan sistem agribisnis pemanfaatan sumberdaya perikanan.

\section{KAJIAN HUKUM PERENCANAAN PEMBANGUNAN NASIONAL}

Indonesia yang memiliki wilayah yang luas, tidak hanya membutuhkan perencaaan pembangunan yang makro, tetapi juga secara sektoral yang tetap sinergis satu sama lain. Koordinasi antar wilayah dan pembangunan berbagai sektor sangat perlu dengan memperhatikan faktor sosial ekonomi, pertumbuhan ekonomi, administrasi pembangunan dan sosial politik negara (Soesastro, 2005). Pencapaian tujuan negara Indonesia tentu harus melalui perencanaan yang menyeluruh dan sejalan dalam setiap bidang dari tataran nasional hingga daerah. Perencanaan nasional merupakan sebuah proses untuk menentukan tindakan masa depan yang tepat, melalui urutan pilihan, dengan memperhitungkan sumber daya yang tersedia, yang dituangkan dalam suatu dokumen sebagai panduan bagi para pelaku pembangunan untuk mencapai tujuan negara (Nurcholis et al., 2007). Dalam menjalankan strategi pembangunan sebuah negara dibutuhkan alur yang jelas dan target yang terukur sehingga nantinya tujuan dari sebuah negara tersebut dapat terwujud. Oleh karena itu, suatu sistem dalam perencanaan pembangunan nasional sangat dibutuhkan dalam hal ini.

Undang-undang Dasar Negara Republik Indonesia Tahun 1945-yang merupakan landasan konstitusional penyelenggaraan negara-dalam waktu relatif singkat (1999-2002) telah mengalami 4 (empat) kali perubahan. Kemudian, sebagai salah satu konsekuensi amandemen ini dikeluarkanlah Undang-Undang Tentang Sistem Perencanaan Pembangunan Nasional (UU No. 25 Tahun 2004, LN Tahun 2004 No. 104, TLN No. 4421). UU No. 25 Tahun 2004 dianggap sebagai dasar perumusan kebijakan sebagai pengejawantahan cita-cita Indonesia. Dalam Penjelasan Umum UU No. 25 Tahun 2004, undang-undang ini dinyatakan sebagai pengganti Garis-garis Besar Haluan negara 
(GBHN). Dimana disebutkan dalam penjelasan umum pengelolaan pembangunan nasional mengalami perubahan sebagai berikut:

1. penguatan kedudukan lembaga legislatif dalam penyusunan Anggaran Pendapatan dan Belanja Negara, (APBN);

2. ditiadakannya Garis-garis Besar Haluan Negara (GBHN) sebagai pedoman penyusunan rencana pernbangunan nasional; dan

3. diperkuatnya Otonomi Daerah dan desentralisasi pemerintahan dalam Negara Kesatuan Republik Indonesia.

Keberadaaan GBHN dan UU No. 25 Tahun 2004, tentu tidak sama dari aspek kedudukan serta fungsi. GBHN sebenarnya memberikan landasan bagi visi dan misi Indonesia secara jangka panjang, yang mana tidak dapat diketemukan dalam UU No. 25 Tahun 2004. Walaupun demikian, UU No. 25 Tahun 2004 dalam Pasal 13, mengamanatkan penetapan rencana pembangunan nasional menjadi produk hukum sehingga mengikat semua pihak untuk melaksanakannya. Sebagai aturan pelaksana dari UU No. 25 Tahun 2004 sebagai perwujudan perencanaan bottom-up adalah PP No. 40 Tahun 2006 Tentang Tata Cara Penyusunan Rencana Pembangunan Nasional (LN Tahun 2006 No. 97, TLN No. 4664) yang memperjelas fungsi dari Musrenbang. Selain itu, rencana pembangunan jangka panjang Nasional/ Daerah ditetapkan sebagai Undang-Undang/ Peraturan Daerah, rencana pembangunan jangka menengah Nasional/Daerah ditetapkan sebagai Peraturan Presiden/Kepala Daerah, dan rencana pembangunan tahunan Nasional/Daerah ditetapkan sebagai Peraturan Presiden/ Kepala Daerah. Maka sebagai perwujudan dari delegasi UU No. 25 Tahun 2004, diundangkanlah UndangUndang Republik Indonesia Nomor 17 Tahun 2007 Tentang Rencana Pembangunan Jangka Panjang Nasional Tahun 2005-2025 (LN Tahun 2007 No. 33, TLN No. 4700). Dalam penetapan Undang-Undang/ Peraturan Daerah akan sangat memakan waktu mulai dari pelaksanaan Musrenbang Kelurahan sampai Musrenbang Nasional serta penggodokan undang-undang/peraturan daerah tersebut.

Pada dasarnya, UU No. 25 Tahun 2004 sebagaimana disebutkan dalam Pasal 2 ayat (4), memiliki tujuan untuk mendukung koordinasi antarpelaku pembangunan, menjamin terciptanya integrasi, sinkronisasi, dan sinergi baik antardaerah, antar ruang antarwaktu, antarfungsi pemerintah maupun antara Pusat dan Daerah. Keberadaan undang-undang ini, diharapkan dapat menjamin keterkaitan dan konsistensi antara perencanaan, penganggaran, pelaksanaan, dan pengawasan serta mengoptimalkan partisipasi masyarakat; dan menjamin tercapainya penggunaan sumber daya secara efisien, efektif, berkeadilan, dan berkelanjutan, sebagaimana cita-cita dalam reformasi Indonesia.

Belakangan diketahui, perencanaan pembangunan yang desentralistik juga malah menghambat pembangunan nasional dengan berpusatnya kekuasaan pada kelompok elit lokal yang berusaha mengkangkangi hukum yang ada (Nurcholis, 2003: 45). Keberadaan UU 25 Tahun 2004 apabila dikaitkan dengan UU No. 32 Tahun 2004 tentang Pemerintahan Daerah (LN Tahun 2004 No. 125, TLN 4437), sangat mendesak untuk diteliti keberlakuannya, karena dengan adanya otonomi daerah sekarang ini akan berdampak pada pola pengambilan kebijakan yang dulunya terpusat menjadi terbagi pada masing-masing daerah. Sehingga kebijakan nasional adakalanya harus diterjemahkan ulang oleh daerah atau bahkan perencanaan nasional tersebut telah didahului oleh daerah. Sehingga tidak menutup kemungkinan terjadi kebijakan ganda dengan anggaran yang berganda juga. Oleh karena itu, mengingat beberapa kemungkinan bias dalam perencanaan pembangunan secara nasional ini, maka sangat dibutuhkan suatu pengkajian mendasar mengenai konsep perencanaan pembangunan nasional, khususnya yang berkaitan nantinya dalam masalah hukum dalam pengelolaan sumber daya kelautan dan perikanan.

\section{KAJIAN HUKUM PENGELOLAAN KELAUTAN DAN PERIKANAN}

Pengelolaan Sumber Daya Kelautan dan Perikanan Indonesia saat ini, terutama mengacu pada UU No. 31 Tahun 2004 Tentang Perikanan (LN Tahun 2004 No.118, TLN No. 4433) sebagaimana telah dirubah dalam UU No 45 Tahun 2009 Tentang Perubahan Atas Undang-Undang Nomor 31 Tahun 2004 Tentang Perikanan (LN Tahun 2009 No. 154 No. 5073). Pemanfaatan sumber daya kelautan dan perikanan sebagaimana diatur dalam peraturan ini belum dipastikan secara jelas dalam pelaksanaannya. Arah pengembangan kebijakan perikanan yang semestinya ditetapkan 
oleh menteri kelautan dan perikanan sebagaimana dimaksud dalam Pasal 7 ayat (1), disebutkan bahwa "Dalam rangka mendukung kebijakan pengelolaan sumber daya ikan, Menteri menetapkan rencana pengelolaan perikanan". Maka sebenarnya fungsi manajerial dan pengambilan kebijakan untuk mengelola sumber daya perikanan tersebut harus benar-benar dijalankan oleh menteri yang bersangkutan.

De Young (2006) menyebutkan bahwa struktur kementerian dalam pengelolaan perikanan dan kelautan adalah sangat penting. Perencanaan pengelolaan yang sinergis mulai dari tahap strategi hingga tahap implementasi teknis oleh organisasi taktis di lapangan akan menentukan keberhasilan suatu kebijakan dan dampak yang akan dirasakan masyarakat. Setiap strategi, yang telah ditetapkan oleh menteri, tentu harus direalisasikan sampai pada tataran paling bawah sekalipun dari kementerian tersebut. Dalam penjabaran dan pelaksanaan suatu kebijakan tersebut nantinya, sangat dibutuhkan konsistensi dan sinergitas dari organisasi di setiap daerah. Sementara, dalam pemerintahan lokal terjadi parochial-participant culture, yang ditandai oleh menguatnya wacana kedaerahan pasca diterapkannya otonomi daerah. Berbagai tekanan agar suatu daerah agar perangkat daerah merupakan putra daerah dan kerap terjadi konflik antar elit-elit lokal menjadi batu sandungan dalam integralisasi sistem pembangunan nasional (Winarno, 2007). Pemahaman terhadap UU No. 32 tahun 2004 tentang Pemerintahan Daerah, harus direvitalisasi agar tidak menjadi faktor penghambat dari berbagai program pemerintah khususnya menteri kelautan dan perikanan secara nasional.

Dalam PP No. 38 Tahun 2007 Tentang Pembagian Urusan Pemerintahan Antara Pemerintah, Pemerintahan Daerah Provinsi, Dan Pemerintahan Daerah Kabupaten/Kota, dinyatakan bahwa kewenangan terkait masalah kelautan dan perikanan merupakan fungsi pilihan sebagaimana disebutkan dalam pasal 7 ayat (4). Sehingga, timbul ketidakpastian dalam menjalankan kewenangan mengenai kelautan dan perikanan dari Kementerian ke setiap pemerintahan daerah. Tidak semua daerah memikul kewajiban mengenai urusan kelautan dan perikanan, sehingga peranan kementerian kelautan dan perikanan dalam merencanakan dan menjalankan kebijakan sektornya memerlukan formulasi khusus karena pengaturan yang ada sementara ini. Ditambah kedudukan peraturan menteri dalam Undang-Undang tentang
Pembentukan Peraturan Perundang-undangan (UU No. 10 Tahun 2004, LN Tahun 2004 LN No. 53, TLN No. 4389) sesuai dengan Pasal 7 ayat (4) hanya diakui keberadaannya dan mempunyai kekuatan hukum mengikat sepanjang diperintahkan oleh Peraturan Perundang-undangan yang lebih tinggi.

UU No 31 tahun 2004 sebagai undangundang yang mengatur tentang sumberdaya perikanan, semestinya merujuk pada UU No 25 Tahun 2004 tentang sistem perencanaan nasional, dalam menjalankan undang-undang tersebut. Peran serta masyarakat yang dinyatakan pada Pasal 6 UU No. 31 Tahun 2004 ini pun harus didefenisikan lagi secara lebih jelas untuk mengantisipasi kebuntuan yang mungkin timbul dari UU No. 32 Tahun 2004 tentang Pemerintahan Daerah. Sehingga, setiap gagasan pengelolaan perikanan nasional yang lebih visioner yang digagas di pusat dapat diterima masing-masing daerah.

Dalam aturan pelaksana UU No. 32 tahun 2004 yaitu PP No. 38 Tahun 2007 dalam Pasal 8, terkait penyelenggaraan urusan wajib pemerintah daerah, apabila pemerintahan daerah yang melalaikannya maka dapat diambil alih oleh pemerintah pusat. Dimana, dalam penyelenggaraan urusan ini, Pemerintah Pusat melakukan langkahlangkah pembinaan terlebih dahulu berupa teguran, instruksi, pemeriksaan, sampai dengan penugasan pejabat Pemerintah ke daerah yang bersangkutan untuk memimpin penyelenggaraan urusan pemerintahan yang bersifat wajib tersebut. Hal-hal seperti inilah, yang tidak ada pengaturannya dalam pengelolaan sumberdaya kelautan dan perikanan. Oleh karena itu, perlu ada kajian hukum yang lebih lanjut dalam menyelesaikan masalah ini, juga dengan memperjelas struktur organisasi yang menjadi berbeda semenjak otonomi daerah berjalan.

Gagasan hukum administrasi kelautan dan perikanan perlu direalisasikan ke depannya. Pengelolaan sumberdaya kelautan dan perikanan, tentu sangat mendesak untuk dilaksananakan. Dimana pengelolaan yang menyeluruh dan sejalan mulai dari pusat hingga daerah akan menentukan keberhasilan dan kebergunaan suatu kebijakan yang telah dicanangkan sebelumnya. Selain itu, permasalahan konflik atau tumpang tindih kewenanga antar sektor juga dapat diminimalisir. Terutama pengelolaan sumber daya kelautan dan perikanan sangat erat kaitannya dengan sektor perindustrian dan perdagangan. Kerangka pengambilan kebijakan yang lintas 
sektoral ditambah dengan adanya otonomi daerah ini menjadi berbeda sama sekali dengan era pemerintahan sebelumnya di Indonesia. Sehingga, harus ada suatu pendekatan hukum administrasi pengelolaan perikanan dan kelautan yang benarbenar baru dan menjawab permasalahan yang ada sekarang ini.

\section{KAJIAN HUKUM PEMERINTAHAN DAN OTONOMI DAERAH}

Undang-Undang Republik Indonesia Nomor 32 Tahun 2004 Tentang Pemerintahan Daerah (LN Tahun 2004 No. 125, TLN 4437) diundangkan dalam rangka penyelenggaraan pemerintahan daerah sesuai dengan amanat Undang-Undang Dasar Negara Republik Indonesia Tahun 1945, pemerintahan daerah, yang mengatur dan mengurus sendiri urusan pemerintahan menurut asas otonomi dan tugas pembantuan, diarahkan untuk mempercepat terwujudnya kesejahteraan masyarakat melalui peningkatan, pelayanan, pemberdayaan, dan peran serta masyarakat, serta peningkatan daya saing daerah dengan memperhatikan prinsip demokrasi, pemerataan, keadilan, keistimewaan dan kekhususan suatu daerah dalam sistem Negara Kesatuan Republik Indonesia.

UU No. 32 Tahun 2004 menyatakan bahwa penyelenggaraan pemerintahan daerah disusun perencanaan pembangunan daerah sebagai satu kesatuan dalam sistem perencanaan pembangunan nasional. Dimana perencanaan pembangunan daerah tersebut disusun oleh pemerintahan daerah provinsi, kabupaten/kota sesuai dengan kewenangannya yang dilaksanakan oleh Badan Perencanaan Pembangunan Daerah. Perencanaan pembangunan daerah tersebut disusun secara berjangka meliputi:

a. Rencana pembangunan jangka panjang daerah disingkat dengan RPJP daerah untuk jangka waktu 20 tahun yang memuat visi, misi, dan arah pembangunan daerah yang mengacu kepada RPJP nasional;

b. Rencana pembangunan jangka menengah daerah yang selanjutnya disebut RPJM daerah untuk jangka waktu 5 (lima) tahun merupakan penjabaran dari visi, misi, dan program kepala daerah yang penyusunannya berpedoman kepada RPJP daerah dengan memperhatikan RPJM nasional;

c. RPJM daerah memuat arah kebijakan keuangan daerah, strategi pembangunan daerah, kebijakan umum, dan program satuan kerja perangkat daerah, lintas satuan kerja perangkat daerah, dan program kewilayahan disertai dengan rencana kerja dalam kerangka regulasi dan kerangka pendanaan yang bersifat indikatif;

d. Rencana kerja pembangunan daerah, selanjutnya disebut RKPD, merupakan penjabaran dari RPJM daerah untuk jangka waktu 1 (satu) tahun, yang memuat rancangan kerangka ekonomi daerah, prioritas pembangunan daerah, rencana kerja dan pendanaannya, baik yang dilaksanakan langsung oleh pemerintah daerah maupun ditempuh dengan mendorong partisipasi masyarakat, dengan mengacu kepada rencana kerja Pemerintah;

UU No. 32 Tahun 2004 dalam pasal 150, mengaharuskan RPJP daerah dan RJMD tersebut ditetapkan dengan Perda berpedoman pada Peraturan Pemerintah. Dengan demikian daerah mengalami dua kali tahapan dengan memperhatikan landasan perencanaan pembangunan nasional yang diatur dalam UU No. 25 tahun 2004 mensyarakatkan perencanaan pembangunan nasional harus melalui Musrenbang Nasional dimana telah ada saringan aspirasi dari masyarakat yang telah mengadakan musrenbang daerah, yang jika ditarik lebih jauh lagi bersumber dari musrenbang kelurahan/desa. Kemungkinan besar, ada persepsi yang agak berbeda dalam berbagai peraturan perundang-undangan di Indonesia khususnya dalam hal ini UU No. 32 Tahun 2004 dan UU No. 25 Tahun 2004. Pada kenyataannya konflik antar sektor di pusat menjadi masalah juga ditambah pembagian kewenangan pusat dan daerah yang juga menambah runyam masalah. Padahal dalam pengelolaan sumber daya kelautan dan perikanan sangat membutuhkan berbagai koordinasi dengan berbagai bidang, yaitu berbagai infrastruktur yang hanya dapat diperoleh dari sektor lain dan pelaksanaannya kerap terbentur masalah batas-batas wilayah geografis antar daerah. Oleh karena itu pembagian kewenangan pusat dan daerah perlu diperhatikan lagi. Tentu saja UU No. 32 Tahun 2004 harus berlandaskan pada semangat UU 25 tahun 2004. Sebagai konsekuensinya, realisasi rencana pembangunan nasional akan disesuaikan nantinya pada masing-masing daerah dengan adanya otonomi masing-masing daerah. Apalagi tentunya dalam hubungan antara provinsi sebagai dan kabupaten/kota seringkali ambigu 
dan kabur batas-batas kewenangannya. Hal ini tentu menjadi salah satu faktor yang mengganggu semangat pembangunan nasional yang terintegrasi sebagaimana diamanatkan UU No. 25 Tahun 2004, sementara UU 32 tahun 2004 sangat kental nuansa desentralisasi dan semangat otonomi daerah itu sendiri. Sementara, dalam UU No. 32 Tahun 2004 sendiri, terutama dalam Pasal 10 disebutkan bahwa Pemerintahan Daerah menyelenggarakan urusan pemerintahan yang menjadi kewenangannya, kecuali urusan pemerintahan yang oleh UndangUndang ini ditentukan menjadi urusan Pemerintah. Dalam menyelenggarakan urusan pemerintahan yang menjadi kewenangan daerah, pemerintahan daerah menjalankan otonomi seluas-luasnya untuk mengatur dan mengurus sendiri urusan pemerintahan berdasarkan asas otonomi dan tugas pembantuan.

\section{KAJIAN HUKUM PENATAAN RUANG DAN BISNIS KELAUTAN DAN PERIKANAN}

Undang-Undang No. 26 Tahun 2007 tentang Penataan Ruang (Lembaran Negara (LN) Tahun 2007 Nomor 68, Tambahan Lembaran Negara (TLN) Nomor 4725) merupakan dasar pengaturan ruang yang meliputi ruang darat, ruang laut, dan ruang udara, termasuk ruang di dalam bumi sebagai satu kesatuan wilayah, tempat manusia dan makhluk lain hidup, melakukan kegiatan, dan memelihara kelangsungan hidupnya. Undang-undang inilah yang menjadi landasan dalam mengelola setiap ruang dan wilayah dalam Negara Kesatuan Republik Indonesia. Maka sebenarnya, UU No. 27 tahun 2007 pun bersumber pada undangundang ini. Walaupun disebutkan juga bahwa pasal 6 ayat (5) bahwa ruang laut dan ruang udara, pengelolaannya diatur dengan undang-undang tersendiri, sehingga Undang-Undang Nomor 27 Tahun 2007 tentang Pengelolaan Wilayah Pesisir Dan Pulau-Pulau Kecil khusus diperuntukkan bagi wilayah yang memiliki pesisir dan pulau-pulau kecil.

Undang-Undang Nomor 27 Tahun 2007 tentang Pengelolaan Wilayah Pesisir Dan PulauPulau Kecil (LN Republik Indonesia Tahun 2007 No.84, TLN Republik Indonesia No.4739) dalam konsideran huruf $b$, dinyatakan secara jelas mengenai Wilayah Pesisir dan Pulau-pulau Kecil Indonesia yang memiliki keragaman potensi sumber daya alam yang tinggi, dan sangat penting bagi pengembangan sosial, ekonomi, budaya, lingkungan, dan penyangga kedaulatan bangsa. Oleh karena itu perlu dikelola secara berkelanjutan dan berwawasaan global, dengan memperhatikan aspirasi dan partisipasi masyarakat, dan tata nilai bangsa yang berdasarkan norma hukum nasional.

Norma-norma Pengelolaan Wilayah Pesisir dan Pulau-Pulau Kecil tersebut disusun dalam lingkup perencanaan, pemanfaatan, pengelolaan, pengendalian, dan pengawasan, dengan memperhatikan norma-norma yang diatur dalam peraturan perundang-undangan lainnya seperti Undang-undang Nomor 26 Tahun 2007 tentang Penataan Ruang (Lembaran Negara Republik Indonesia Tahun 2007 Nomor 68, Tambahan Lembaran Negara Republik Indonesia Nomor 4725). Norma-norma Pengelolaan Wilayah Pesisir dan Pulau-Pulau Kecil yang akan dimuat difokuskan pada norma hukum yang belum diatur dalam sistem peraturan perundang-undangan yang ada atau bersifat lebih spesifik dari pengaturan umum yang telah diundangkan.

UU No. 26 Tahun 2007 memiliki peraturan pelaksana yaitu Peraturan Menteri Dalam Negeri Nomor 29 Tahun 2008 Tentang Pengembangan Kawasan Strategis Cepat Tumbuh Di Daerah. Sementara, UU No 27 Tahun 2007 juga mensyaratkan aturan turunan yaitu Peraturan Menteri Kelautan Dan Perikanan Republik Indonesia Nomor Per.12/Men/2010 tentang Minapolitan. Dimana, kedua peratuan menteri dari kementerian yang berbeda ini, diharapkan akan sinergis pada pelaksaksanaannya. Rencana tata ruang ataupun zonasi sebagaimana disebutkan dalam pasal 7 huruf a Peraturan Menteri Kelautan Dan Perikanan Republik Indonesia Nomor Per.12/ Men/2010, mensyaratkan kesesuaian dengan Rencana Strategis, Rencana Tata Ruang Wilayah (RTRW) dan/atau Rencana Zonasi Pengelolaan Wilayah Pesisir dan Pulau-Pulau Kecil (RZWP-3-K) kabupaten/kota, serta Rencana Pengembangan Investasi Jangka Menengah Daerah (RPIJMD) yang telah ditetapkan.

Pengelolaan wilayah sangat bergantung pada sektor dan bidang yang akan digarap. Pada akhirnya, suatu daerah paling tidak akan menggarap dua perencanaan ruang dan wilayah yaitu khusus untuk bagian darat serta bagian pesisir dan pulaupulau kecil. Oleh karena itu, jelaslah bahwa penataan ruang saat ini khususnya sektoral setiap instansi, tetapi masing-masing dilakukan di daerah sehingga menjadi kendala dalam setiap pelaksanaannya. Pemerintah daerah pun harus diperhadapkan pada kewajiban membuat dua rancangan wilayah dari sektor yang berbeda dalam suatu wilayah geografis 
dan administratif yang sama. Tentu tidak mudah membuat aturan yang seperti ini, ditambah sumber hukum di atasnya bersumber dari peraturan yang berbeda dengan kepentingan berbeda pula.

Dalam pengembangan pengelolaan sumber daya kelautan dan perikanan, investasi sangat dibutuhkan sebagai faktor pendorong pertumbuhan ekonomi dan meningkatkan kesejahteraan masyarakat, khususnya nelayan (Zulham dan Purnomo, 2010). Kemitraan antara pemilik modal dan masyarakat yang menggeluti bidang perikanan perlu ditingkatkan dengan adanya sebuah lingkungan pengaturan (legal environment) yang pro rakyat.

\section{PENUTUP}

Pendekatan hukum dan pembangunan merupakan pendekatan yang sangat relevan dalam upaya mendukung pembangunan kelautan dan perikanan. Dalam hal ini, tidak saja sebagai salah satu sektor ekonomi, tetapi juga akan membantu para pengambil kebijakan di bidang kelautan dan perikanan. Tujuannya adalah untuk mengevaluasi efektivitas pelaksanaan dari rencana-rencana pembangunan, sehingga pada gilirannya dapat melakukan perencanaan yang lebih baik lagi. Pemanfaatan sumber daya kelautan dan perikanan sebagaimana diatur dalam peraturan yang ada hingga saat ini belum dipastikan secara jelas dalam pelaksanaannya.

Arah pengembangan kebijakan perikanan semestinya ditetapkan oleh menteri kelautan dan perikanan. Fungsi manajerial dan pengambilan kebijakan untuk mengelola sumber daya perikanan tersebut harus benar-benar dijalankan oleh menteri yang bersangkutan. Perencanaan pengelolaan yang sinergis mulai dari tahap strategi hingga tahap implementasi teknis oleh organisasi taktis di lapangan akan menentukan keberhasilan suatu kebijakan dan dampak yang akan dirasakan masyarakat.

Suatu daerah paling tidak akan menggarap dua perencanaan ruang dan wilayah yaitu khusus untuk bagian darat serta bagian pesisir dan pulaupulau kecil. Dalam pengembangan pengelolaan sumber daya kelautan dan perikanan, investasi sangat dibutuhkan sebagai faktor pendorong pertumbuhan ekonomi dan meningkatkan kesejahteraan masyarakat, khususnya nelayan. Kemitraan antara pemilik modal dan masyarakat yang menggeluti bidang perikanan perlu ditingkatkan dengan adanya sebuah lingkungan pengaturan (legal environment) yang pro rakyat.

\section{DAFTAR PUSTAKA}

Abdurrahman, M. 2009. Sosiologi dan Metode Penelitian Hukum. UMM Press. Malang.

De Young, C. 2006. Review of the state of world marine capture fisheries management: Indian Ocean. Rome: Food and Agriculture Organization of the United Nations FAO Fisheries Technical Paper 488. HIm. 5-25.

Indonesia. 2009. UUD 1945 (Amandemen Lengkap) \& Susunan Kabinet 2009-2014. Pustaka Yustisia. Yogyakarta.

2009. Undang-Undang Republik Indonesia Tentang Perubahan Atas Undang-Undang Nomor 31 Tahun 2004 Tentang Perikanan. UU RI No.45 Tahun 2009. LN Thn.2009 No.154. TLN No.5073.

2007. Undang-Undang Republik Indonesia Tentang Penataan Ruang. UU RI No.26 Tahun 2007. LN Thn.2007 No.68 TLN No.4725.

. 2007. Undang-Undang Republik Indonesia Tentang Pengelolaan Wilayah Pesisir dan Pulau-Pulau Kecil. UU RI No. 27 Tahun 2007. LN Thn.2007 No.84. TLN No.4739.

2004. Undang-Undang Republik Indonesia tentang Pembentukan Peraturan Perundang-undangan. UU RI No. 10 Tahun 2004. LN Thn.2004 No.53 TLN No.4389.

2004. Undang-Undang Republik Indonesia Tentang Sistem Perencanaan Pembangunan Nasional. UU No. 25 Tahun 2004. LN Thn.2004 No.104, TLN No.4421.

. 2004. Undang-Undang Republik Indonesia Tentang Pemerintahan Daerah. UU RI No.32 Tahun 2004. LN Thn.2004 No.125 TLN No.4437.

2004. Undang-Undang Republik Indonesia Tentang Perikanan. UU RI No.31 Tahun 2004. LN Thn.2004 No.118 TLN No.4433

Nurcholis, H. 2003. Teori dan Praktik: Pemerintahan dan Otonomi Daerah (Rev). Grasindo. Jakarta.

Soekanto, S. 2010. Pengantar Penelitian Hukum. Penerbit Universitas Indonesia. Jakarta 277 hlm. 
Siombo, M.R. 2010. Hukum Perikanan Nasional dan Internasional. PT Gramedia Pustaka Utama. Jakarta. $273 \mathrm{hlm}$.

Soesastro, H. 2005. Pemikiran dan Permasalahan Ekonomi di Indonesia dalam setengah abad terakhir: Buku 3 (1966-1982) Paruh Pertama Ekonomi Orde Baru. Kanisius. Yogyakarta.

Supriatna, J. 2008. Melestarikan Alam Indonesia. Yayasan Obor Indonesia. Jakarta. $482 \mathrm{hlm}$

Umar. M.H. 2003. Masalah Pembangunan dan Penegakan Hukum Kelautan di Indonesia. http://docs.google.com/ gview?url=http://www.lfip.org/english/pdf/ bali-seminar/masalah+pemb + dan+penegakan+hukum+kelautan+husseyn+umar. pdf\&chrome=true. Tanggal akses: 5 Juni 2011.

Winarno, B. 2007. Sistem Politik Indonesia Era Reformasi. Medpress. Yogyakarta. $286 \mathrm{hlm}$

Zulham, A. \& A. H. Purnomo. 2010. Minapolitan: dari Konsep Menuju Implementasi. Balai Besar Riset Sosial Ekonomi Kelautan dan Perikanan. Badan Penelitian dan Pengembangan Kelautan dan Perikanan Kementerian Kelautan dan Perikanan. Jakarta 